\title{
Parasitoid Distribution and Parasitism of the Fall Armyworm Spodoptera frugiperda (Lepidoptera: Noctuidae) in Different Maize Producing Regions of Uganda
}

\author{
Michael Hilary Otim ${ }^{1, *} \mathbb{\oplus}$, Stella Adumo Aropet ${ }^{1}$, Moses Opio ${ }^{1}$, Dalton Kanyesigye ${ }^{1} \mathbb{C}$, Henry Nakelet Opolot ${ }^{2}$ \\ and Wee Tek Tay ${ }^{3}$ \\ 1 National Crops Resources Research Institute (NaCRRI), Kampala P.O. Box 7084, Uganda; \\ stellaadumo@yahoo.com (S.A.A.); opio.moses@yahoo.com (M.O.); kanyesigyedalton@gmail.com (D.K.) \\ 2 Ministry of Agriculture, Animal Industry and Fisheries, Entebbe P.O. Box 102, Uganda; hnopolot@gmail.com \\ 3 Black Mountain Laboratories, Clunies Ross Street, Commonwealth Scientific and Industrial Research \\ Organisation, Canberra 2601, Australia; Weetek.Tay@csiro.au \\ * Correspondence: motim9405@gmail.com or motim@naro.go.ug
}

check for updates

Citation: Otim, M.H.; Adumo Aropet, S.; Opio, M.; Kanyesigye, D.; Nakelet Opolot, H.; Tek Tay, W. Parasitoid Distribution and Parasitism of the Fall Armyworm Spodoptera frugiperda (Lepidoptera: Noctuidae) in Different Maize Producing Regions of Uganda. Insects 2021, 12, 121. https://doi.org/ $10.3390 /$ insects 12020121

Academic Editor: Gábor L. Lövei

Received: 23 December 2020

Accepted: 23 January 2021

Published: 29 January 2021

Publisher's Note: MDPI stays neutral with regard to jurisdictional claims in published maps and institutional affiliations.

Copyright: (c) 2021 by the authors. Licensee MDPI, Basel, Switzerland. This article is an open access article distributed under the terms and conditions of the Creative Commons Attribution (CC BY) license (https:// creativecommons.org/licenses/by/ $4.0 /)$.
Simple Summary: The fall armyworm (FAW), a native of the Americas that was confirmed in Africa in 2016, has been reported to cause substantial damage to maize and sorghum in all subSaharan African countries. In Uganda, farmers rely mainly on synthetic insecticides, which can be harmful to humans, the environment, and significantly increase the cost of production. To lessen the disadvantages associated with synthetic insecticides, the use of parasitoids could be exploited. Fall armyworm parasitoids have been reported from the Americas, Asia, and some African countries, but not from Uganda. In this study, we aimed to determine the identity and distribution of FAW parasitoids in Uganda. We found 13 species of parasitoids attacking FAW in the surveyed locations. These included 11 species of insects in the wasp order and two in the fly order. Four of these are wasps that attack the eggs of FAW, while the remaining seven wasps and two fly species attack the larvae of FAW. Two wasp genera (Chelonus and Coccygidium spp.) were more abundant and widely distributed when compared with the other parasitoid species. All parasitoids contributed to an average of $9.2 \%$ FAW larval mortality rate across the study locations.

Abstract: The fall armyworm (FAW) Spodoptera frugiperda (J.E. Smith) (Lepidoptera: Noctuidae) has successfully invaded Africa, where it has significantly impacted maize and sorghum production. Management of FAW in Africa predominantly relies on synthetic insecticides, which are expensive, and negatively impact the environment and beneficial insects. We, therefore, conducted field surveys in Uganda in 2017 and 2019 to identify egg and larval parasitoids of FAW for possible use in integrated pest management (IPM) programs. Parasitoids were identified by their mitochondrial DNA cytochrome c oxidase subunit 1 (mtCOI) gene sequences. We identified 13 parasitoid species belonging to three families of Hymenoptera: Platygastridae, Braconidae and Ichneumonidae, as well as one Dipteran family (Tachinidae). Coccygidium spp. and Chelonus bifoveolatus were the most abundant and widely distributed parasitoids. Overall, parasitism averaged $9.2 \%$ and ranged from $3.1 \%$ to $50 \%$ in 2017 , and $0.8 \%$ to $33 \%$ in 2019 . Parasitism by Sturmiopsis parasitica, Diolcogaster sp., and Cotesia flavipes on FAW in maize crops are reported for the first time. Our results suggest high biological diversity of FAW parasitoids, which should be exploited in the IPM of the FAW in Uganda.

Keywords: Charops cf. diversipes; Chelonus bifoveolatus; Coccygidium luteum; Cotesia flavipes; Cotesia icipe; Sturmiopsis parasitica; Telenomus remus; beneficial insects

\section{Introduction}

The fall armyworm (FAW) Spodoptera frugiperda (J.E. Smith) (Lepidoptera: Noctuidae), a native to the tropical and sub-tropical regions of the Americas, was first reported in West 
Africa from Nigeria, and the island of São Tomé and Principe in 2016 [1], and subsequently in almost all sub-Saharan African countries [2-7]. The estimated yield losses ranged from 8.3 to 20.6 million tons of maize in Africa, valued yearly at USD 2481-6187 million [8]. In Uganda, FAW was estimated as capable of causing maize losses of 558.9 to 1391 tons annually under no control, translating to USD 163.7 to 407.5 million annually [8]. However, recent field studies in Uganda found that FAW, which is now in all maize growing districts of Uganda, can cause grain yield losses of up to $50 \%$ or more under severe infestation and drought conditions (MH Otim, unpubl. data), highlighting the economic impact of this invasive pest in East Africa.

In the Americas, chemical insecticides, genetically modified maize/cotton/soy, resistant varieties, and augmentative control methods are used to manage FAW [8]. In Africa, smallholder farmers manage FAW using synthetic insecticides [9-11], and several other practices including early planting, handpicking of FAW eggs and larvae, frequent weeding, manure and fertilizer applications, destruction of infested plants, application of sand and ash, crop rotation, habitat management (e.g., maize intercropped with Greenleaf desmodium (Desmodium intortum)), with Bracharia planted around the intercrop [12], and intercropping. Cultural practices alone, however, have limited effectiveness against this pest given its high migratory behavior and reproductive capacity [13]. The use of insecticides is associated with increased costs of production, dangers to human health, and negative impact to the environment and beneficial insects [14]. Prolonged use of synthetic insecticides could lead to the development of resistance in target pest species. Insecticide resistance in FAW was detected in the New World (e.g., [15-17]) as well as in introduced populations (e.g., [18-20]) and this generates economic and biosecurity concerns. The management of FAW should, therefore, explore alternative options including the use of beneficial insects where possible.

Integrating biological control for more sustainable control of the pest has been encouraged in many African countries, including Uganda [21]. The use of introduced or locally occurring biological control agents can reduce FAW outbreaks and provide a more economic and environmentally friendly option. Natural enemies are an important mortality factor of FAW in several places. The reported natural enemies include fungi [22,23], bacteria [24], viruses and Microsporidia [24], parasitoids [21], and entomopathogenic nematodes [23]. In the Americas, FAW is attacked by an assemblage of parasitoids (approximately 150 species) [22,23,25-33]. Across the invasive range of FAW, several parasitoids have been identified (e.g., China [34]; India [35,36]). In Africa, reports of parasitoids attacking FAW have come from South Africa, Côte d'Ivoire, Ethiopia, Kenya, Niger, Benin, and Tanzania [37-39]. The lack of studies on parasitoids attacking FAW from Uganda, therefore, limits the development of biological control of this pest in the country.

Here, we report on an exploratory study of the occurrence of FAW parasitoids, their relative abundance, and parasitism in maize crops from eastern, central, northern, and western regions of Uganda in 2017 and 2019. We used a combination of morphological and molecular species diagnostic methods to identify the parasitoid species. We highlight existing challenges and outline future research opportunities on potential uses of these FAW parasitoids as candidate biological control agents for integrated pest management (IPM) of this important pest.

\section{Materials and Methods}

\subsection{Survey for FAW and Natural Enemies}

We conducted surveys for FAW parasitoids in 99 districts of Uganda across the eastern, central, northern, and western regions (Figure 1) in 2017 and 2019. In each region, representative maize producing districts were surveyed based on guidance by the District Production Departments and availability of maize in the field. We sampled 50 maize plants per field from two or three sub-counties (two fields per sub-county) per district, separated by at least $3 \mathrm{~km}$. While walking diagonally across the field, each selected plant was visually inspected for the presence of FAW eggs and larvae. The eggs and larvae of FAW were identified based on the described characteristics [31]. Egg batches were placed in petri 
dishes containing a piece of moistened filter paper while larvae were individually placed in propylene vials, and provided with maize leaf as food. The collected samples were transported to the laboratory for further observation.

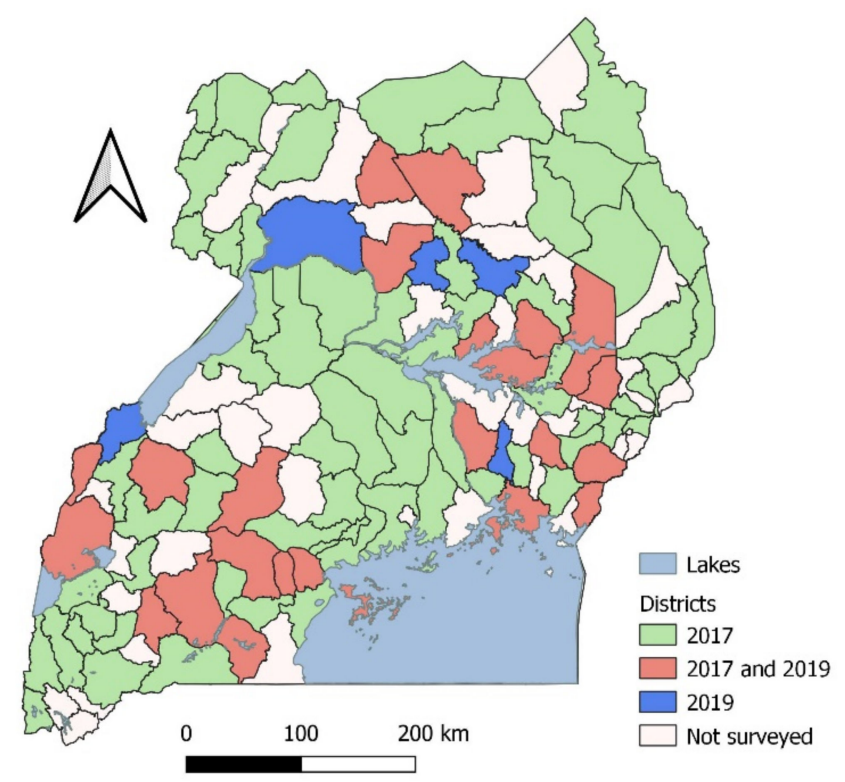

Figure 1. Map of Uganda showing districts in which surveys for fall armyworm parasitoids were conducted in 2017 (green), 2019 (dark blue), and 2017 and 2019 (red). Districts not surveyed have been left blank.

\subsection{Rearing and Identification of Parasitoids}

Collected FAW eggs and larvae were incubated at 12:12 h light:dark duration, RH 65.5 $\pm 0.27 \%$, and temperature $25.8 \pm 0.071{ }^{\circ} \mathrm{C}$ in the laboratory for emergence of parasitoids, or FAW larvae and adults, respectively. For adult parasitoid emergence or pupa pupal development, we kept the larvae on fresh maize leaves, which were replenished as needed. Emerged parasitoids were recorded daily and preserved in $90 \%$ ethanol. We did not dissect the dead larvae and pupae to check for the presence of parasitoids. Emerged parasitoids were examined and identified to the family/genus level using published identification guides for Platygastridae [40], Braconids [41-43], Ichneumonidae [44], and Tachinidae [45,46]. This was followed by DNA barcoding to confirm the identity of the parasitoids (details described below). Voucher specimens are stored at the National Crops Resources Research Institute, Namulonge, Uganda. The samples used for DNA barcoding comprised 40 individuals (Coccygidium spp. (9), Chelonus sp. (9), Tachinidae (6), Telenomus (4), unknown Platygastridae (1), Diolcogaster (1), Meteorus (1), Cotesia spp (4), and Charop sp (5)). The number was dictated by the number of individuals of each taxon that were reared.

\subsection{DNA Extraction}

The DNA from individual parasitoids was extracted using the chelex method [5]. All insects were rinsed twice with sterile molecular grade water (Thermo Fisher Scientific, UK) to wash off the ethanol used for preservation. Using a clean sterile surgical blade, a leg of each specimen was excised and placed in a sterile $1.5 \mathrm{~mL}$ micro-centrifuge tube. For smaller parasitoids (e.g., Telenomus spp. and Cotesia spp.) the entire insect was used. For each specimen, we added $50 \mu \mathrm{L}$ of $10 \%$ Chelex 100 solution followed by $10 \mu \mathrm{L}$ $(20 \mathrm{mg} / \mathrm{mL})$ of proteinase $\mathrm{K}$ solution. Each sample was incubated at $56{ }^{\circ} \mathrm{C}$ overnight, followed by a brief vortex then heat inactivation at $100^{\circ} \mathrm{C}$ for $15 \mathrm{~min}$. The resulting mixture was centrifuged at 15,900 relative centrifugal forces (rcf) for 3 min and $40 \mu \mathrm{L}$ supernatant was stored at $-20^{\circ} \mathrm{C}$. This stock DNA was used for PCR amplification. The unused portion of parasitoids was stored in absolute ethanol and kept at $-20^{\circ} \mathrm{C}$ for future reference. 


\subsection{PCR Amplification of COI Segments}

The mitochondrial DNA cytochrome c oxidase subunit 1 (mtCOI) gene of all parasitoid samples was amplified by polymerase chain reaction (PCR) using the LCO1490 and $\mathrm{HCO} 2198$ primer set [47] in a $25 \mu \mathrm{L}$ volume per reaction. The PCR mixture consisted of $16.25 \mu \mathrm{L}$ of nuclease free water (ThermoFisher Scientific), $2.5 \mu \mathrm{L}$ of $10 \times$ Dream Taq green buffer, $0.5 \mu \mathrm{L}$ deoxynucleotide triphosphate (dNPTs) $(10 \mathrm{mM}), 1 \mu \mathrm{L}$ of each primer (10 Pmol $/ \mu \mathrm{L}), 0.25 \mu \mathrm{L}$ of Dream Taq DNA polymerase (ThermoFisher-Scientific), $2.5 \mu \mathrm{L}$ of $5 \%$ Tween 20 and $1 \mu \mathrm{L}$ of the template DNA. The PCR thermo-cycling conditions were: $94{ }^{\circ} \mathrm{C}(2 \mathrm{~min})$ for initial denaturation, followed by 35 cycles of $94{ }^{\circ} \mathrm{C}(30 \mathrm{~s}), 52{ }^{\circ} \mathrm{C}$ (35 s), and $72{ }^{\circ} \mathrm{C}(45 \mathrm{~s})$, and a final extension step at $72{ }^{\circ} \mathrm{C}$ for $10 \mathrm{~min}$. Post PCR reactions were stored at $4{ }^{\circ} \mathrm{C}$ until needed. PCR products were visualized by electrophoresis in $1 \times \mathrm{TAE}$ buffer $1.5 \%(w / v)$ agarose gels (UltraPure Agarose, Invitrogen, Carlsbad, CA, USA) stained with $5 \mu \mathrm{L}$ of ethidium bromide, visualized under UV light to confirm the presence of amplicon products, and photographed using a digital camera in U: GENIUS3 gel documentation system.

\subsection{Sequencing and Sequence Analysis}

All PCR products were sent to Macrogen Europe (1105 AZ, Amsterdam, The Netherlands) for purification and sequencing. We used the Pregap4 and Gap4 sequence analysis programs within the Staden sequence analysis package [48] to analyze trace files and assemble contigs. Nine sequences (Coccygidium (5) and Chelonus (4)) were discarded either because they were short or dirty sequences. Geneious ${ }^{\circledR} 11.1 .3$ (https:/ / www.geneious.com) [49] was used to translate DNA nucleotide sequences to protein sequences using invertebrate mitochondrial genetic code, and choosing the appropriate reading frame to confirm the absence of premature stop codons. All our partial sequences were not pseudogenes or nuclear mitochondrial (NuMT) sequences because of the absence of premature stop codons. Assembled partial $\mathrm{mtCOI}$ sequences from all parasitoid specimens were compared to sequences in GenBank via Blast search program against the non-redundant (nr) DNA database [50], and where necessary compared also to the International Barcode of Life (iBoL) database [51] to assist with species molecular identification.

\subsection{Phylogenetic Analysis}

Phylogenetic analyses were not carried out where there was limited information available from GenBank or iBoL for assignment of parasitoid identity (i.e., only to Family level, e.g., Platygastridae), or where species identity could be confidently assigned due to a high degree of shared nucleotide identity. Phylogenetic analyses were performed if our unknown parasitoid sequences shared a high degree of nucleotide similarity known from iBoL or GenBank. Phylogenetic analyses were carried out for the two hymenopteran genera as described below, without rooting because our interest was not to define their phylogenies but rather to ascertain if our sequences would cluster with particular taxa and their associated statistical confidence.

\subsubsection{Telenomus spp.}

Two of the four Telenomus mtCOI sequences (MT780201, MT780202) shared a high level of nucleotide similarity with $T$. remus. To determine the species status of the remaining Telenomus samples (MT782153, MT782154), we applied a phylogenetic approach by combining these unknown sequences with other Telenomus genus/Platygastridae family sequences from GenBank (accessed 12 July 2020). Sequences downloaded from GenBank and our five Platygastridae candidate sequences were imported into Geneious 11.1.5 (Biomatters Ltd., Auckland, New Zealand) for alignment using MAFFT alignment v7.450 [52,53] with default settings (Algorithm: Auto; Scoring Matrix: 200 PAM/K = 2; Gap open penalty: 1.53; Offset value: 0.123 ). All sequences were trimmed to $560 \mathrm{bp}$ to retain maximum sequence length. Sequences shorter than $560 \mathrm{bp}$ and excess identical (redundant) sequences sharing $100 \%$ sequence identity were excluded while retaining a maximum of two identical se- 
quences for each unique haplotype. The resulting non-redundant sequences were analyzed using IQ-Tree [54] <http: / / iqtree.cibiv.univie.ac.at> with the automatic substitution model and by selecting 1000 ultrafast bootstrap replication options to estimate the confidence of branch nodes. The resulting unrooted phylogeny was visualized and presented using Dendroscope (version 3.5.7, built 30 Jan 2016; [55]) (Figure S1).

\subsubsection{Coccygidium spp.}

A total of 44 partial mtCOI sequences from the iBoL $(n=33)$ and GenBank $(n=11)$ were downloaded (accessed 26 April 2020), as well as two outgroup individuals (Agathis sp. H15103 (KP943649); Agathis sp. H15112 (KP943651); GenBank accessed 12 December 2020), and aligned with our three Ugandan Coccygidium sequences from GenBank (MT784160, MT784186, MT784187). We removed redundant sequences (i.e., those sharing $100 \%$ sequence identity) and short sequences, and trimmed the remaining $596 \mathrm{bp}$ for maximum sequence length. Trimmed sequences were aligned and used to infer phylogenetic relationships to help assess the confidence of species assignment based on nucleotide similarity. Inference of the Coccygidium spp. phylogeny and phylogenetic tree visualization with the Agathis individuals as the outgroup were as described for Telenomus spp.

\subsection{Relative Abundance and Parasitism Rates}

Relative abundance (RA) was expressed as a percentage of the total number of parasitoids of a particular species (ni) to the total number of all parasitoids that were reared $(\mathrm{N})$ (Equation (1)).

$$
R A=(n i \div N) \times 100
$$

Percent of parasitism (Para) by different species was expressed as the ratio of the total number of parasitized FAW larvae $(n)$ and the total number of FAW larvae collected from a particular district $(\mathrm{N})$. The figures were adjusted for the gregarious larval parasitoid (C. flavipes) that had more than one adult parasitoid emerging from a single larva. In this case, the number of parasitized larvae was taken as one regardless of the number of parasitoids that emerged from it.

\section{Results}

In 2017, we recovered parasitoids from 32 of the 96 districts sampled. In 2019, we recovered parasitoids from 18 of the 31 districts sampled.

In total, we recovered 13 species attacking FAW in the surveyed locations, including egg, egg/larval, larval, and larval/pupal parasitoids (Table 1). The egg parasitoids included two species of Telenomus: T. remus Nixon and Telenomus sp., and an unidentified Platygastrid (all Hymenoptera: Platygastridae) that matched to Telenomus $s p$. at $87.44 \%$ nucleotide identity. The sequences of the five egg/larval parasitoids recovered from FAW matched Chelonus bifoveolatus Szépligeti (Hymenoptera: Braconidae) with a $99.8 \%$ to $100 \%$ sequence identity. The larval parasitoids included Coccygidium luteum (Brullé, 1846), Coccygidium sp., Cotesia flavipes (Cameron), Cotesia icipe Fernandez-Triana and Fiaboe, and Diolcogaster sp. (all Hymenoptera: Braconidae) and Charops cf. diversipes (Hymenoptera: Ichneumonidae). The larval/pupal parasitoids were Meteorus sp. (Hymenoptera: Braconidae) and two species of Tachinidae: Sturmiopsis parasitica (Curran) and Drino quadrizonula (Thomson).

\subsection{Distribution of Egg Parasitoids}

Telenomus remus: This constituted $60 \%$ of the egg parasitoids reared, and was recovered from FAW eggs collected from Bukedea and Ntoroko Districts, eastern and western regions, respectively (Table 2 ).

Telenomus sp. constituted $37 \%$ of the total egg parasitoids reared and was $96.6 \%$ identical to T. remus (Table 1). This Telenomus sp. was recovered from Soroti District (eastern region) and Mbarara (western region). 
Table 1. Parasitoid species recovered from eggs and larvae of Spodoptera frugiperda collected from maize fields in Uganda, 2017 and 2019 and their sequence identity as compared with publicly available sequences from GenBank and iBoL entries.

\begin{tabular}{|c|c|c|c|c|}
\hline Order, Family, and Species & $\begin{array}{l}\text { GenBank Accession No. of } \\
\text { Ugandan Parasitoids }\end{array}$ & Host Stage Attacked & $\begin{array}{c}\text { Species with Closest } \\
\text { NucleoTide Sequence Match }\end{array}$ & $\begin{array}{l}\text { Percent Identity, and Reference } \\
\text { GenBank Accession Number and } \\
\text { iBoL Entries }\end{array}$ \\
\hline \multicolumn{5}{|l|}{$\begin{array}{l}\text { Hymenoptera: } \\
\text { Platygastridae }\end{array}$} \\
\hline Telenomus remus Dixon & MT780201, MT780202 & Eggs & Telenomus remus & 100\% (MK533751) [38] \\
\hline Telenomus sp. & MT782153 and MT782154 & Eggs & Telenomus remus & $96.6 \%$ (MK533751) [38] \\
\hline $\begin{array}{c}\text { Platygastridae sp. } \\
\text { Hymenoptera: Braconidae }\end{array}$ & MT784162 & Eggs & Telenomus sp. & $87.4 \%$ (KR878931) \\
\hline Chelonus bifoveolatus & MT776316 to MT776320 & Egg/larvae & Chelonus bifoveolatus & $\begin{array}{l}\text { 99.8-100\% (KX051941) [56]; } \\
\text { MN900744, MN900743 [39]) }\end{array}$ \\
\hline $\begin{array}{l}\text { Coccygidium luteum } \\
\text { Coccygidium sp. }\end{array}$ & $\begin{array}{c}\text { MT784186, MT784187 } \\
\text { MT784160 }\end{array}$ & $\begin{array}{l}\text { Larvae } \\
\text { Larvae }\end{array}$ & $\begin{array}{l}\text { Coccygidium. luteum } \\
\text { Coccygidium sp. } 3\end{array}$ & $\begin{array}{c}\text { 99.64\%; (MN900741) [39]) } \\
\text { 98.2\%; (MF098368) }\end{array}$ \\
\hline Cotesia flavipes & MT780220 & Larvae & Cotesia flavipes & $\begin{array}{l}\text { 100\% (JF865973) and 99.6\% } \\
\text { (MN900741; MN900728) [39] }\end{array}$ \\
\hline Cotesia icipe & MT780217 to MT780219 & Larvae & Cotesia icipe & $\begin{array}{c}\text { 100\% (iBoL ID JMIC0355) and 99.6\% } \\
\text { (MN900741; MN900728) [39] and } \\
100 \% \text { (JMIC0355) }\end{array}$ \\
\hline $\begin{array}{l}\text { Diolcogaster sp. } \\
\text { Meteorus sp. } \\
\text { Hymenoptera: } \\
\text { Ichneumonidae }\end{array}$ & $\begin{array}{l}\text { MT784194 } \\
\text { MT784161 }\end{array}$ & $\begin{array}{c}\text { Larvae } \\
\text { Larvae/pupae }\end{array}$ & $\begin{array}{l}\text { Diolcogaster sp. } \\
\text { Meteorus sp. }\end{array}$ & $\begin{array}{c}\text { 98.38\% (HM397609) } \\
\text { 99.84\% (MF673599) [57]) }\end{array}$ \\
\hline $\begin{array}{l}\text { Charops cf. diversipes } \\
\text { Diptera: Tachinidae }\end{array}$ & MT784179 to MT784183 & Larvae & Charops cf. diversipes & $99.8-100 \%$ (MN900729) [39] \\
\hline Sturmiopsis parasitica(Curran) & MT784184 and MT784185 & Larvae/pupae & Sturmiopsisparasitica & 99.35\% (DQ336399) \\
\hline Drino quadrizonula & MT784175 to MT784178 & Larvae/pupae & Drino quadrizonula & $99.28-99.8 \%$ (MN907776) [39]) \\
\hline
\end{tabular}

Table 2. Occurrence and relative abundance of egg parasitoids recovered from Spodoptera frugiperda in different districts of Uganda in 2019. + Nucleotide identity to Telenomus remus (MK533751) at 96.6\%.

\begin{tabular}{cccc}
\hline Region & District & Species & Relative Abundance (\%) $(\boldsymbol{n}=\mathbf{3 5})$ \\
\hline \multirow{2}{*}{ Eastern } & Bukedea & Telenomus remus & 28.6 \\
& Soroti & Telenomus sp. + & 14.3 \\
& Nestern & Platygastridae & 2.9 \\
& Ntoroko & Telenomus remus & 31.4 \\
& Mbarara & Telenomus sp. + & 22.9 \\
\hline
\end{tabular}

Platygastridae sp. This taxon shared $87.3 \%$ identity with Telenomus sp. (GenBank MK533751) (Table 1), and accounted for 3\% of the egg parasitoids (Table 2). It was recovered from Ntoroko district in Western Uganda.

\section{Phylogenetic relationships among the Platygastridae}

We used a total of 193 Platygastroidea and one Chalcidoidea partial mtCOI sequences that included species within the Telenomus genus (from 250 GenBank downloaded sequences; accessed 12 July 2020) for phylogenetic inferences (and also included our four detected candidate Telenomus sequences and one Platygastridae sequence) to help assess their species status. Uncorrected pairwise nucleotide distances ( $p$-dist) between all 199 trimmed and aligned sequences ranged from $0 \%$ to $17.9 \%$ (i.e., $82.1-100 \%$ sequence identity). We identified at least 21 subclades within the trimmed and aligned sequences, with at least 13 subclades containing sequences from specimens previously identified as Telenomus species (Figure S1).

Based on the uncorrected $p$-dist estimates, the Ugandan Telenomus sequences (GenBank MT780201, MT780202) shared 100\% sequence identity with T. remus (MK533751) and clustered confidently ( $99 \%$ node support value) with the partial mtCOI sequences of five previously reported T. remus individuals from Benin (MK533751), India (KT305960, KP994550), and China (MN123243, MN123244) ( $p$-dist: 0-0.53\%). Two other sequences (GenBank MT780153, MT780154) clustered as a basal sister species with T. remus (p-dist: 4.07-7.26\%) and Telenomus spp. from Canada ( $p$-dist: 8.14-8.85\%), suggesting that the two identical Telenomus sequences (GenBank MT780153, MT780154) from Uganda likely represented a novel African species that was also capable of parasitizing FAW.

The Ugandan Platygastridae sequence (GenBank accession no. MT784162) was the most divergent sequence amongst the 194 sequences from the Platygastroidea/Chalcidoidea 
Superfamilies with nucleotide similarity that ranged from 82.14\% (MG355758, Platygastridae sp.)/ 86.25\% (MH926817, Chalcidoidea) to 87.86\% (KR803447, Telenomus sp.).

\subsection{Distribution of Egg/Larval Parasitoids of Spodoptera Frugiperda Chelonus bifoveolatus}

We reared Che. bifoveolatus from larvae of FAW in both 2017 and 2019 (Table 3). Our sequences shared $99.6 \%$ to $100 \%$ identity with Che. bifoveolatus reported in Ghana, Benin, and French Polynesia (GenBank KX052941, MN900743, MN900744).

Table 3. Total larvae and parasitism of Spodoptera frugiperda larvae collected from different districts of Uganda in 2017. No. par $=$ total parasitoids recovered; Para $=\%$ parasitism; Chb = Chelonus bifoveolatus; Col = Coccygidium luteum; Cos = Coccygidium sp; Chd = Charops cf. diversipes; $\mathrm{Spa}=$ Sturmiopsis parasitica $;$ Dri = Drino quadrizonula.

\begin{tabular}{|c|c|c|c|c|c|c|c|c|c|}
\hline \multirow[b]{3}{*}{ Region/District } & \multirow[b]{3}{*}{ No. Larvae Collected } & \multirow[b]{3}{*}{ No. Parasitoids Recovered } & \multirow[b]{3}{*}{ Overall Parasitism, $\%$} & \multicolumn{6}{|c|}{ Host Stage Attacked, Parasitoid Species } \\
\hline & & & & \multicolumn{2}{|c|}{ Egg/Larva } & \multicolumn{2}{|l|}{ Larva } & \multicolumn{2}{|c|}{ Larva/Pupa } \\
\hline & & & & Chb & Col & $\operatorname{Cos}$ & Cha & Spa & Dri \\
\hline \multicolumn{10}{|l|}{ Central } \\
\hline Sembabule & 2 & 1 & 50 & & & & & & 50 \\
\hline \multicolumn{10}{|l|}{ Eastern } \\
\hline Amuria & 33 & 1 & 3 & & & 3 & & & \\
\hline Bukedea & 67 & 1 & 1.5 & & & 1.5 & & & \\
\hline Kaberamaido & 29 & 3 & 10.3 & 6.9 & & 3.4 & & & \\
\hline Kamuli & 15 & 1 & 6.7 & & & 6.7 & & & \\
\hline Katakwi & 35 & 4 & 11.4 & 8.6 & & 2.9 & & & \\
\hline Kumi & 42 & 5 & 11.9 & 4.8 & & 4.8 & & & 2.4 \\
\hline Mayuge & 46 & 2 & 4.3 & 4.3 & & & & & \\
\hline Namutumba & 22 & 4 & 18.1 & & 13.6 & & & & 4.5 \\
\hline Pallisa & 58 & 1 & 1.7 & & 1.7 & & & & \\
\hline Serere & 32 & 1 & 3.1 & 3.1 & & & & & \\
\hline Sironko & 40 & 1 & 2.5 & & & & 2.5 & & \\
\hline Soroti & 30 & 3 & 10 & 3.3 & & 6.7 & & & \\
\hline \multicolumn{10}{|l|}{ Northern } \\
\hline Adjumani & 14 & 2 & 14.3 & & & 14.3 & & & \\
\hline Alebtong & 10 & 2 & 20 & 20 & & & & & \\
\hline Dokolo & 32 & 2 & 6.3 & 3.1 & & & 3.1 & & \\
\hline Gulu & 24 & 1 & 4.2 & & & 4.2 & & & \\
\hline Kaabong & 37 & 3 & 8.1 & 5.4 & & 2.7 & & & \\
\hline Kole & 30 & 1 & 3.3 & 3.3 & & & & & \\
\hline Kotido & 42 & 4 & 9.5 & 9.5 & & & & & \\
\hline Lira & 40 & 4 & 10 & & 10 & & & & \\
\hline Maracha & 75 & 1 & 1.3 & & & 1.3 & & & \\
\hline Moroto & 9 & 1 & 11.1 & & & & & & 11.1 \\
\hline Moyo & 23 & 3 & 13 & & 13 & & & & \\
\hline Nebbi & 36 & 5 & 13.9 & & & 13.9 & & & \\
\hline Nwoya & 26 & 2 & 7.6 & 3.8 & & 3.8 & & & \\
\hline Oyam & 19 & 2 & 10.6 & & & & & 5.3 & 5.3 \\
\hline Pader & 35 & 4 & 11.4 & & & 11.4 & & & \\
\hline Pakwach & 24 & 1 & 4.2 & 4.2 & & & & & \\
\hline Yumbe & 39 & 2 & 5.1 & & & 5.1 & & & \\
\hline Zombo & 36 & 2 & 5.6 & & 5.6 & & & & \\
\hline \multicolumn{10}{|l|}{ Western } \\
\hline Kasese & 35 & 3 & 8.6 & 8.6 & & & & & \\
\hline
\end{tabular}

In 2017, Chelonus bifoveolatus was recovered from 14 districts (Alebtong, Dokolo, Kaabong, Kaberamaido, Kasese, Katakwi, Kole, Kotido, Kumi, Mayuge, Nwoya, Pakwach, Serere and Soroti districts; Table 3). In 2019, Che. bifoveolatus was recovered from nine districts (Alebtong, Kasese, Katakwi, Kole, Luuka, Mayuge, Nwoya, Serere, and Soroti) in eastern, northern, and western regions (Table 4).

\subsection{Distribution of Larval Parasitoids of Spodoptera Frugiperda}

The larval parasitoids recovered included two species of Coccygidium (Coc. luteum and Coccygidium sp.), two species of Cotesia (Cot. flavipes and Cot. icipe), and a Diolcogaster sp. (Table 1).

\subsubsection{Coccygidium Luteum and Coccygidium sp.}

Our Coccygidium luteum (MT784186, MT784187) shared 99.7\% sequence identity with the Coc. luteum reported from Ghana (GenBank accession MN900741) and the Republic of Congo (MF098367; iBoL: ATRMK048-09), and clustered confidently (100\%) as a clade (Figure 2, red branches). It was recovered from five districts in Eastern and Northern 
Uganda in the 2017 survey (Table 3) and two districts in the 2019 survey in Eastern Uganda (Table 4). The remaining one Coccygidium sequence from Uganda (MT784160) clustered with a high node support value of $81 \%$ with two Coccygidium sequences from the Republic of Congo (i.e., iBOL accession numbers ATRMK004-09, ATRMK045-09). This formed a sisterclade ( $95 \%$ node confidence value) with four Coccygidium sequences (i.e., iBoL accession numbers ATRMK003-09, ATRMK006-09, ATRMK046-09; GenBank MF098368, named as "Coccygidium sp. 3 EGC-2017" [58]), also from the Republic of Congo, and these sequences (blue branches) appeared paraphyletic as sister clades to Coc. luteum (with an average uncorrected $p$-dist of 3.8\%, data not shown), suggesting that at least another undescribed "non-Coccygidium sp. 3" was present in both Uganda and the Republic of Congo and could use FAW as a reproductive host. This unidentified Ugandan Coccygidium sp. (MT784160) was recovered from 15 districts in 2017 survey in eastern and northern regions (Table 3). In the 2019 survey, we only recovered the "non-Coccygidium sp. 3" (GenBank MT784160) from five districts in central, northern, and western regions (Table 4).

Table 4. Total larvae and parasitism of Spodoptera frugiperda larvae collected from different districts of Uganda in 2019. No. par = total parasitoids recovered; Para = parasitism; $\mathrm{Chb}=$ Chelonus bifoveolatus; $\mathrm{Col}=$ Coccygidium luteum; Cos = Coccygidium sp.; Cof = Cotesia flavipes; Coi = Cotesia icipe; Dio = Diolcogaster sp.; Met = Meteorus sp.; Chd = Charops cf. diversipes; Spa $=$ Sturmiopsis parasitica $;$ Dri = Drino quadrizonula .

\begin{tabular}{|c|c|c|c|c|c|c|c|c|c|c|c|c|c|}
\hline \multirow[b]{3}{*}{ Region/District } & \multirow[b]{3}{*}{$\begin{array}{l}\text { No. Larvae } \\
\text { Collected }\end{array}$} & \multirow[b]{3}{*}{$\begin{array}{l}\text { No. Parasitoids } \\
\text { Recovered }\end{array}$} & \multirow[b]{3}{*}{ Overall Parasitism, \% } & \multicolumn{10}{|c|}{ Host Stage Attacked, Parasitoid Species } \\
\hline & & & & \multicolumn{2}{|c|}{ Egg/Larva } & \multicolumn{3}{|c|}{ Larva } & \multicolumn{5}{|c|}{ Larva/Pupa } \\
\hline & & & & Chb & Col & $\operatorname{Cos}$ & Cof & Coi & Dio & Cha & Met & Spa & Dri \\
\hline \multicolumn{14}{|l|}{ Central } \\
\hline Mubende & 20 & 1 & 5 & & & 5 & & & & & & & \\
\hline Sembabule & 3 & 1 & 33.3 & & & & & & & & & 33.3 & \\
\hline \multicolumn{14}{|l|}{ Eastern } \\
\hline Bukedea & 21 & 1 & 4.8 & & & & & & & 4.8 & & & \\
\hline Busia & 32 & 2 & 6.2 & & & & & 3.1 & & 3.1 & & & \\
\hline Kaberamaido & 24 & 1 & 4.2 & & & 4.2 & & & & & & & \\
\hline Kamuli & 48 & 2 & 4.1 & & & 2.1 & & 2.1 & & & & & \\
\hline Katakwi & 19 & 1 & 5.3 & 5.3 & & & & & & & & & \\
\hline Kumi & 27 & 3 & 11.1 & & & & & & & & 3.7 & & 7.4 \\
\hline Luuka & 74 & 1 & 1.4 & 1.4 & & & & & & & & & \\
\hline Mayuge & 49 & 1 & 2 & 2 & & & & & & & & & \\
\hline Namutumba & 30 & 3 & 10 & & 6.7 & & & & & & & & 3.3 \\
\hline Serere & 28 & 1 & 3.6 & 3.6 & & & & & & & & & \\
\hline Soroti & 30 & 6 & 20 & 16.7 & 3.3 & & & & & & & & \\
\hline \multicolumn{14}{|l|}{ Northern } \\
\hline Alebtong & 119 & 1 & 0.8 & 0.8 & & & & & & & & & \\
\hline Gulu & 58 & 1 & 1.7 & & & 1.7 & & & & & & & \\
\hline Kole & 59 & 10 & 17 & 5.1 & & & & & 11.9 & & & & \\
\hline Nwoya & 42 & 4 & 9.5 & 4.8 & & 2.4 & 2.4 & & & & & & \\
\hline \multicolumn{14}{|l|}{ Western } \\
\hline Kasese & 31 & 5 & 16.1 & 9.7 & & & & 3.2 & & 3.2 & & & \\
\hline
\end{tabular}

\subsubsection{Cotesia flavipes}

The Cotesia flavipes recovered in this study has high sequence homology matching with previously reported Cot. flavipes partial mtCOI sequences (i.e., 100\% matched GenBank JF865973 and 99.6\% matched GenBank MN900741). Cot. flavipes was recovered only in the 2019 survey from Nwoya District in Northern Uganda (Table 4).

\subsubsection{Cotesia Icipe}

The Cotesia icipe that we recovered in this study had a partial mtCOI gene sequence that matched 100\% with Cot. icipe (BOLD museum ID JMIC0355) and $99.6 \%$ matched with MN900741 reported in Ghana (Table 1). This parasitoid was recovered only in the 2019 survey from Busia and Kamuli Districts in Eastern Uganda, and Kasese District in Western Uganda (Table 4). 


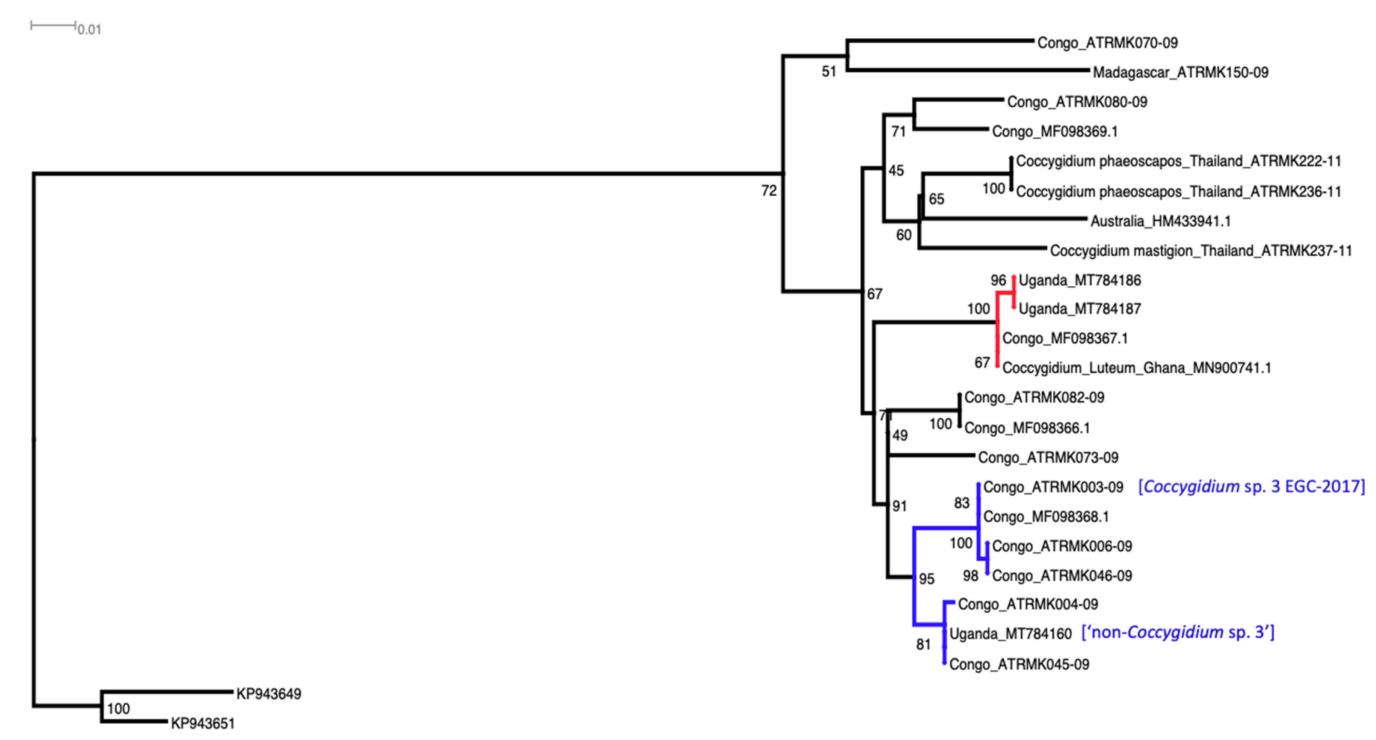

Figure 2. Phylogenetic placements of the Ugandan Coccygidium species, with two of the three sequences (GenBank MT784186, MT784187) being shown to cluster confidently with Coc. luteum from Ghana (MN900741) and Congo (MF098367), and the remaining one (GenBank MT784160) clustered with sequences as the sister clade to the "Coccygidium. sp. 3 EGC-2017" individual (GenBank MF098368). The outgroup individuals were Agathis spp. from Mexico (KP943649) and the United States of America (KP943651) [59].

\subsubsection{Diolcogaster sp.}

This species was recovered from Oyam in Northern Uganda in 2019 (Table 4) and shared 98.38\% nucleotide sequence identity with a previously reported Diolcogaster sp. from Guanacaste, Costa Rica (GenBank HM397609), suggesting that these two Diolcogaster specimens were potentially the same or very closely related species.

\subsection{Distribution of Larval/Pupal Parasitoids of Spodoptera Frugiperda}

We recovered four species of larval/pupal parasitoids. These were two hymenopteran species (Meteorus sp., Charops cf. diversipes), and two dipteran species (Sturmiopsis parasitica and Drino quadrizonula).

\subsubsection{Meteorus sp.}

The Meterous species shared $99.84 \%$ of nucleotide with the Meteorus sp. recovered from Senegal (GenBank MF673599, Table 1) and was, therefore, likely to be the same species. This parasitoid was recovered from FAW sampled from Kumi in 2019 (Table 4).

\subsubsection{Charops cf. Diversipes}

This species shared 99.8-100\% nucleotide identity with Charops cf. diversipes reported from Ghana (GenBank MN900729). It was recovered from FAW samples collected from Kasese and Bukedea.

\subsubsection{Sturmiopsis parasitica}

Sturmiopsis parasitica recovered from our study shared $99.35 \%$ identity with previously reported S. parasitica from Zimbabwe (GenBank DQ336399) (Table 1). This species was recovered in Oyam District in Northern Uganda in 2017 (Table 3) and from Sembabule District in Central Uganda in 2019 (Table 4).

\subsubsection{Drino quadrizonula}

This tachinid shared 99.28-99.8\% sequence identity with Drino quadrizonula (GenBank MN907776) (Table 1) from the Barcode of Life database [51]. This species was recovered from 
five districts in Central, Eastern, and Northern Uganda in 2017 (Table 3). In the 2019 survey, it was recovered from Kumi and Namutumba in Eastern Uganda (Table 4).

\subsection{Relative Abundance and Parasitism of Spodoptera Frugiperda Eggs and Larvae}

In the 2017, survey, the most abundant parasitoids of FAW were Coccygidium spp. and Che. bifoveolatus spp. (Figure 3). The other larval parasitoids were rare. In 2019, Cot. flavipes and Che. bifoveolatus were the most abundant (Figure 4). The other rare but recovered species in 2019 were Coccygidium spp., Charops cf. diversipes, Cot. icipe, D. quadrizonula, Meteorus sp., and S. parasitica.

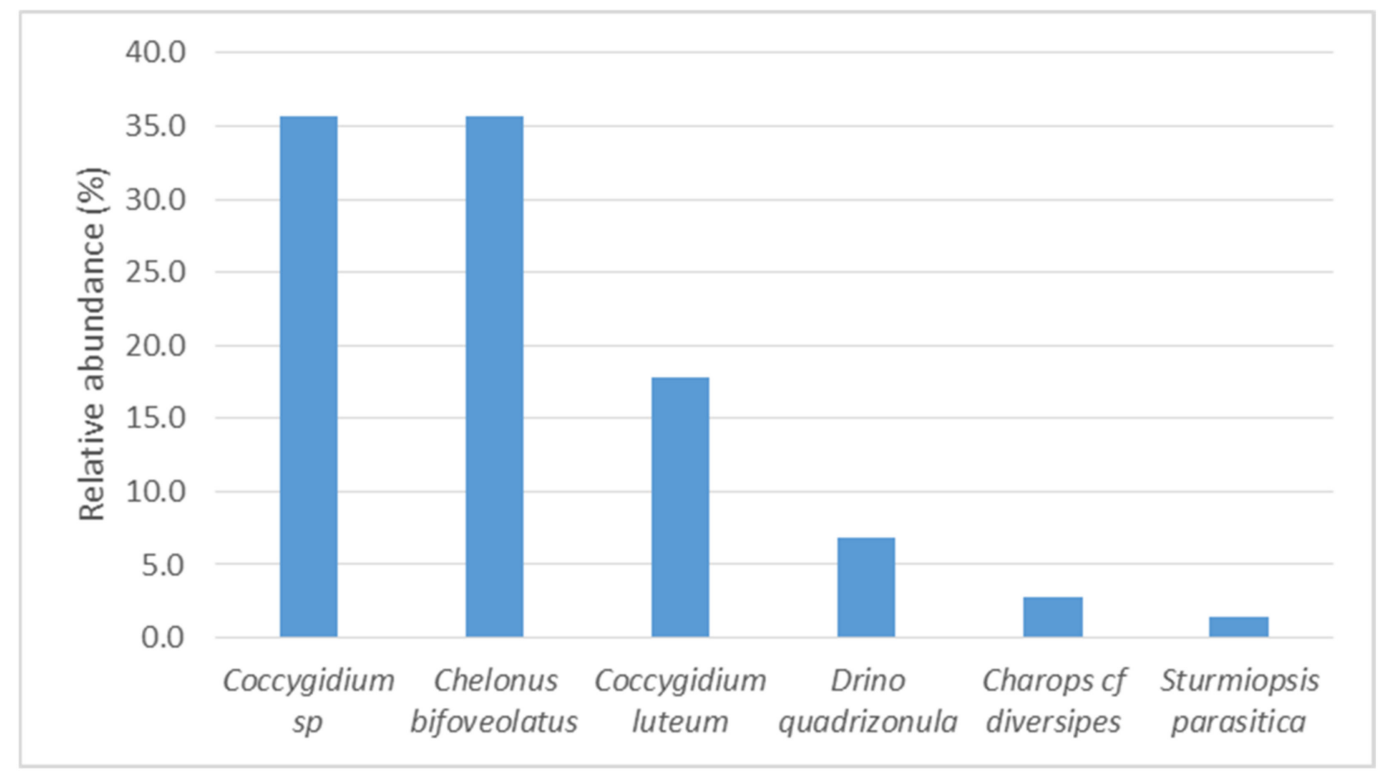

Figure 3. Relative abundance of parasitoid species of Spodoptera frugiperda larvae in 2017 across all surveyed districts in Uganda.

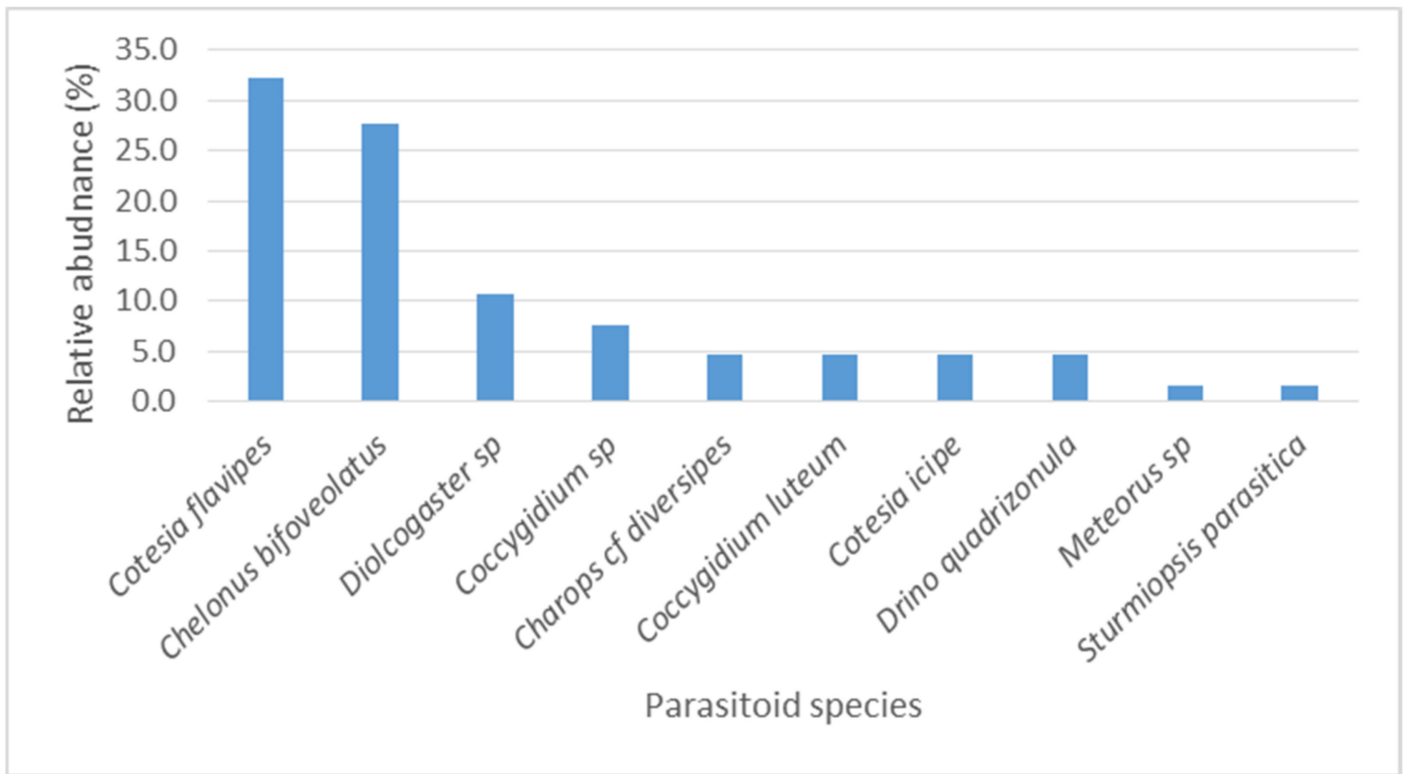

Figure 4. Relative abundance of parasitoid species of Spodoptera frugiperda larvae in 2019 across all surveyed districts in Uganda. 
Egg parasitism was not evaluated as counts were not made of the total number of eggs or neonates that emerged. Total larval parasitism ranged from 1.3\% to 50\% in 2017 (Table 3) and $0.8 \%$ to $33 \%$ in 2019 (Table 4). In 2017, total larval parasitism was highest in the central region $(50 \%)$, and lower elsewhere: eastern $(10.2 \%)$, northern $(8.9 \%)$, and western $(8.6 \%)$ regions. In 2019, total larval parasitism was also highest in the central region (19.2\%), and lower in western $(9.7 \%)$, northern $(7.2 \%)$, and eastern $(6.6 \%)$ regions.

\section{Discussions}

We recovered 13 species of parasitoids attacking FAW in different regions of Uganda. These belong to three families of Hymenoptera: Platygastridae (three species), Braconidae (seven species) and Ichneumonidae (one species) and one Dipteran family (two species of Tachinidae). The most widely distributed and abundant parasitoids in our study were Coccygidium and Chelonus spp. In this study, we also report (for the first time) parasitism by S. parasitica, Diolcogaster sp., Drino quadrizonula, and Cot. flavipes on FAW in maize crops in East Africa. Parasitism was averaged as $9.2 \%$ across all the locations and sampling times.

\subsection{Coccygidium spp.}

In our study, we report two Coccygidium species (Coccygidium luteum and an unknown putative novel Coccygidium sp. MT784160) parasitizing FAW in Uganda (Figure 2). Coccygidium luteum has previously been reported from Cameroon, Congo, Democratic Republic of Congo, Ethiopia, Ghana, Guinea, Kenya, Madagascar, Mauritius, Mozambique, Namibia, Niger, Nigeria, Rodriques Island, Réunion, Senegal, Seychelles, Somalia, South Africa, Tanzania, and Yemen in Asia [37,39,60,61]. This parasitoid reduced FAW leaf consumption by up to $89 \%$ under laboratory conditions and was thus identified as a candidate biological control agent for augmentative release [62]. There is, however, no report on the augmentative release of Coccygidium in Africa. In India, FAW is reported to be parasitized by Coc. transcaspicum in northwestern India [63] and Coc. melleum in southern India [64] (both Hymenoptera: Braconidae).

In the review by Ranga-Rao et al. [65], Coc. luteum, Coc. siss oo (Hymenoptera: Braconidae) and Coc. melleum were reported to parasitize Spodoptera exigua larvae. Sequences from GenBank and iBoL revealed the occurrence of other Coccygidium spp. in other geographical regions (e.g., Coc. phaeoscapos (Hymenoptera: Braconidae) (Thailand); Coccygidium sp. (Townsville, Australia, HM433941), with at least 20 Coccygidium species known in Australia [66]. The existence of many species of Coccygidium distributed across the current invasive range of FAW suggests that some of the endemic Coccygidium species could potentially be candidate agents for control of FAW, although species recorded from South East Asia (e.g., Thailand) and Oceania (e.g., Australia) appeared basal to the African Coccygidium species that have been identified to parasitize FAW (see Figure 2). Despite the importance of Coccygidium parasitoids on economically important Spodoptera species, there remains a significant knowledge gap on species identity and the ecological services they provide for managing FAW in various parts of Africa, S.E. Asia, and Australia.

\subsection{Chelonus Bifoveolatus}

The Chelonus species recorded in Uganda matched the partial mtCOI sequences of Che. bifoveolatus that had previously been reported from FAW in Ghana, Benin, and Tanzania [39,67]. This widespread Chelonus species recovered in various regions of Uganda also matched partial mtCOI sequences of unidentified Chelonus spp. from Asia including India (e.g., Che. formosanus (Hymenoptera: Braconidae), [36]), French Polynesia and Pakistan. The Chelonus genus is the most common and widely distributed parasitoid of FAW in the Americas and Africa. In Colombia, Che. inuslaris parasitizes eggs of FAW, but is very susceptible to insecticides such as chlorpyriphos, methomyl, and cypermethrin but not to Bt toxin [68]. In the Caribbean Islands, Che. antillarum Marshall (Hymenoptera: Braconidae) was reported parasitizing FAW [26].

Chelonus species are globally distributed (e.g., See $[65,69])$. In Australia, at least 45 endemic species have been reported that includes Che. scrobiculatus (Szépligeti) and Che. anomala (both Hymenoptera: Braconidae) (reported from Queensland and Western Aus- 
tralia, as well as the Caribbean nation of Trinidad and Tobago; ALA accessed 23 October 2019) (see Kittel et al. [69] for review). The mtCO1 sequences of unidentified Australian Chelonus species (KJ472543, KJ438520, KJ472553) showed 84.77 to $88.44 \%$ pairwise nucleotide similarity with the Ugandan Che. bifoveolatus (GenBank MT776316) across 444 bp of partial mtCOI gene, suggesting that different species occur in the two countries. Diversity of the Chelonus parasitoids across the recent invasive range of the FAW should be investigated as this parasitoid genus could represent significant biological resources that have adaptive traits to their respective geographic range and could be used effectively to manage FAW and related Spodoptera species (e.g., S. litura (Lepidoptera: Noctuidae), [65] across different ecoclimatic zones.

\subsection{Telenomus spp.}

We recovered T. remus and an unidentified species of Telenomus. T. remus has been reported globally based on publicly available sequences (e.g., from GenBank and iBoL [51,70]). In Africa, it has been recorded in South Africa, Benin, Ivory Coast, Niger, Kenya, and now also in Uganda (this study) [38,39]. The presence of T. remus in Uganda offers promise for the control of FAW eggs. Indeed, T. remus was identified as an effective parasitoid of FAW eggs capable of causing $64 \%$ and $78 \%$ parasitism in the field and screenhouse in Niger [71], respectively, and is known to occur in several other African countries [38]. Because of its occurrence in Africa, emphases should be placed on conducting more distribution, effectiveness, and mass production studies, rather than exploring options for importation into Africa.

The sequences of the second Telenomus sp. shared $95.92 \%$ sequence identity with our T. remus sequence, suggesting that this is likely a different Telenomus sp. whose sequence has not been reported. The identity of the unknown Telenomus sp. in our study remains to be ascertained. Nevertheless, this Telenomus species could be an endemic African/Ugandan Telenomus species that could also serve as important biological agents against the invasive FAW. Therefore, its biology, ecology, effectiveness, and amenability for mass production and augmentative release should also be studied for inclusion in FAW IPM.

\subsection{Tachinidae spp.}

We recovered two species of Tachinidae flies: S. parasitica and D. quadrizonula. This is the first report of S. parasitica parasitizing FAW. Earlier, S. parasitica was reported to parasitize B. fusca in Congo [72] and, Eldana saccharina Walker (Lepidoptera: Pyralidae), and Busseola fusca (Fuller) and Sesamia spp. (both Lepidoptera: Noctuidae) in Ghana [73]. In our study, only two individuals were recovered, thus making it a minor contributor to the population dynamics of FAW from our initial assessments. The second tachinid had a close match with Drino quadrizonula reported from Ghana and Benin [39]. The was also a minor parasitoid of FAW in Uganda and various countries it has been recovered from.

\subsection{Cotesia spp.}

Three Ugandan Cotesia matched the recently named Cot. icipe, which was reported as the most prevalent parasitoid of FAW in Ethiopia and was also recovered in Kenya [39]. One Ugandan sample also matched Cot. flavipes [74]. Originating from the Indo-Asia region, Cot. flavipes is economically important and has been introduced into Africa and the New World for biocontrol of stem borers [75]. Elsewhere, Cot. Marginiventris was recovered from S. frugiperda in Mexico [76], while Cot. scotti was reported as attacking Spodoptera cosmioides (Walker) (Lepidoptera: Noctuidae) and Spodoptera eridania (Stoll) (Lepidoptera: Noctuidae) in Brazil [77]. In sub-Saharan Africa, Cot. icipe has been shown in laboratory experiments to be effective against Spodoptera species although efficacies against S. frugiperda and Spodoptera exempta (Walker) (Lepidoptera: Noctuidae) remain to be assessed [42]. Despite the ecological importance of these braconid wasps, little is known of how they interact and respond to their lepidopteran hosts [78], their population size, population dynamics, and interactions with their natural enemies [79], factors that 
may underpin our understanding of how the parasitoid populations persist across the landscape to impact on their respective lepidopteran hosts.

\subsection{Charops cf. Diversipes}

Charops ater has been reported to widely parasitize FAW larvae in Tanzania and Kenya [37] in 2017. Our study identified the Charops species from FAW larval samples collected from Busia, Bukedea, Sironko, and Dokolo Districts as C. cf. diversipes, sharing $99.29 \%-100 \%$ nucleotide identity with samples from Benin and Ghana [39]. This species of parasitoid could be further exploited for FAW control given its presence in several African countries and regions of Uganda.

\subsection{Meteorus sp.}

Only one individual of Meteorus sp. was recovered from FAW in Uganda. This suggests that it is a minor biocontrol agent of FAW in Uganda. Meteorus species have, however, been recovered from FAW on maize in Mexico [27,76], Florida (USA) [33], and Northern Sinaloa (Mexico) [80]. In most of these cases, it was a minor parasitoid. In Africa, Meteorus spp. have also been recovered from millet head miner moth Heliocheilus albipunctella De Joannis (Lepidoptera: Noctuidae), a noctuid pest of pearl millet [57].

\subsection{Diolcogaster sp.}

This is the first record of Diolcogaster attacking FAW in Africa. These are largely undescribed species of Microgastrinae, with nine species described in the Nearctic realm [81] and two from the Americas [82]. This species is likely a minor parasitoid of FAW given a single recovery.

\subsection{Parasitism of FAW Larvae}

Our study has shown that indigenous parasitoids, including parasitoids of lepidopteran stemborers, were capable of parasitizing FAW in Uganda. This is promising and further suggests that biological control will have a vital role in the integrated management of FAW. The overall level of parasitism by the different parasitoids was generally low, averaging $9.2 \%$. This compares with the $9.5 \%$ parasitism of FAW reported in Mozambique [83]. The parasitism rate by Che. bifoveolatus observed in this study ( $0.8 \%$ to $16.7 \%)$ was also generally lower than those reported in Ghana where parasitism ranged from $0 \%$ to $35.6 \%$ [39]. In Senegal, $10.9 \%$ parasitism of FAW larvae by Chelonus sp. was reported [84]. In the case of Coc. luteum, parasitism levels of 4.6, 5.0, and 8.3\% were recorded in Ethiopia, Tanzania, and Kenya, respectively [37]. In Uganda, however, parasitism by Coc. luteum ranged from $3.3 \%$ to $13.6 \%$. Parasitism by Cot. icipe ranged from $2.1 \%$ to $3.2 \%$ in our study, sharply contrasting with earlier studies that showed higher parasitism levels of $5.6 \%$ in Kenya and $22.8 \%$ to $45.3 \%$ in Ethiopia [37].

Many factors influence parasitism rates. In Uganda, farmers adopted heavy application of mainly organophosphate broad-spectrum insecticides to control FAW. This would likely impact the abundance of natural enemies of FAW. Indeed, parasitism was highest in untreated plots than in plots treated with biopesticides (Metarhizium anisopliae and Beauveria bassiana) and the synthetic insecticide flubendiamide in Tanzania [67]. Consequently, any attempt to integrate biologically based measures to manage FAW will require options that do not significantly impact the activity of parasitoids.

\section{Study Limitations}

Our study was designed to provide preliminary knowledge of FAW parasitoid species diversity in Uganda such that follow-up studies with meaningful and testable hypotheses could be undertaken. Nevertheless, while limited in scope and survey frequencies, it represents one of the first surveys in Uganda to understand the diversity of parasitoids with the capacity to use FAW as an alternative host. Our study highlights the need for more widespread and frequent surveys, and more detailed population dynamics studies 
not only for Africa but for the current geographic range of the invasive populations of FAW (e.g., S.E. Asia, Australia), as well as potential future spread range (e.g., South Pacific, southern Europe, the Near East, northern Africa). More surveys will aid in documenting additional natural enemies and their impact, while population dynamics studies are needed to understand the role of different factors on the incidence and abundance of FAW and its natural enemies. The study of egg parasitoids was not detailed in the present study, and focus should therefore be placed on identifying egg parasitoids and to assess their efficiency in the management of FAW. Where promising parasitoids are identified, it would be important to develop protocols for mass production and distribution to other parts of the country.

\section{Conclusions and Recommendations}

We have shown that FAW is attacked by at least 13 species of parasitoids in the surveyed districts of Uganda. The most abundant parasitoids (i.e., Coccygidium and Chelonus spp.) and their use as candidate biocontrol agents for augmentative control and IPM programs and impact by synthetic insecticides and biopesticides remain areas to be explored. With the endemic and introduced parasitoid species capable of attacking FAW, the country should focus on understanding the tritrophic interactions between parasitoids, their FAW hosts and plant hosts, and ecological and biological factors, to harness the benefits afforded by the existing and most promising parasitoids in Uganda. There will be a need for more detailed studies to document indigenous parasitoid recruitment by FAW and to assess, under controlled conditions, the effectiveness of selected species for biological control.

Supplementary Materials: The following are available online at https:/ / www.mdpi.com/2075-4 450/12/2/121/s1, Figure S1. Platygastridae unrooted phylogeny as inferred from 560 bp partial mtCOI sequences using IQ-Tree with 1000 bootstrap replications to estimate branch node confidence. Telenomus remus sequences are (GenBank accession numbers: MT780201 and MT780202), and the unknown Ugandan Telenomus species is represented by (GenBank accession numbers: MT780153 and MT780154). The unknown Platygastridae from Uganda is represented by (GenBank accession number MT784162) and indicated by the red colored branch, with poor phylogeny placement together with the Indonesian Mymaridae (MH926817). Note that this is an unrooted tree (i.e., no outgroup was defined and included for analysis) and is meant to assist with estimating confidences of clustered (i.e., related) sequences within the large assemblage of parasitoids species within the Telenomus genera.

Author Contributions: Conceptualization, M.H.O.; data curation, M.O.; formal analysis, M.H.O., M.O., D.K. and W.T.T.; funding acquisition, M.H.O., H.N.O. and W.T.T.; investigation, M.H.O., S.A.A., M.O. and D.K.; methodology, M.H.O., D.K. and W.T.T.; project administration, M.H.O.; resources, M.H.O., H.N.O. and W.T.T.; supervision, M.H.O., S.A.A. and H.N.O.; visualization, D.K. and W.T.T.; writing-original draft, M.H.O., S.A.A. and W.T.T.; writing—review and editing, M.O., S.A.A., M.O., H.N.O., D.K. and W.T.T. All authors have read and agreed to the published version of the manuscript.

Funding: M.H.O., S.A.A, M.O., D.K. and H.N.O. acknowledge funding from the Agricultural Technology and Agribusiness Advisory Services Project (Project ID No. P109224) and the Agriculture Cluster Development Project (Project ID No. P145037) both funded by the World Bank. WTT acknowledges funding support from CSIRO Health and Biosecurity (R-91044-01, R-8681-1).

Institutional Review Board Statement: Not applicable.

Informed Consent Statement: Not applicable.

Data Availability Statement: The data presented in this study are available on request from the corresponding author.

Acknowledgments: We are grateful to Peter Wasswa, George RwothOmio, Damalie Oguli, Florence Aryenyo, and Geresmu Omuut for assistance in the laboratory. Tonny Amodoi is acknowledged for data entry. WTT was supported by CSIRO Health and Biosecurity. We thank Betty Stephanie Apica for reviewing the manuscript.

Conflicts of Interest: The authors declare no conflict of interest. 


\section{References}

1. Goergen, G.; Kumar, P.L.; Sankung, S.B.; Togola, A.; Tamò, M. First report of outbreaks of the fall armyworm Spodoptera frugiperda (J E Smith) (Lepidoptera: Noctuidae), a new alien invasive pest in West and Central Africa. PLoS ONE 2016, 11, e0165632. [CrossRef] [PubMed]

2. Cock, M.J.W.; Beseh, P.K.; Buddie, A.G.; Cafá, G.; Crozier, J. Molecular methods to detect Spodoptera frugiperda in Ghana, and implications for monitoring the spread of invasive species in developing countries. Sci. Rep. 2017, 7, 4103. [CrossRef]

3. Food and Agriculture Organization. Briefing Note on FAO Actions on Fall Armyworm; Brief Note 03; FAO: Rome, Italy, 2018; pp. 1-6.

4. Nagoshi, R.N.; Koffi, D.; Agboka, K.; Tounou, K.A.; Banerjee, R.; Jurat-Fuentes, J.L.; Meagher, R.L. Comparative molecular analyses of invasive fall armyworm in Togo reveal strong similarities to populations from the eastern United States and the Greater Antilles. PLoS ONE 2017, 12, e0181982. [CrossRef] [PubMed]

5. Otim, M.H.; Tay, W.T.; Walsh, T.K.; Kanyesigye, D.; Adumo, S.; Abongosi, J.; Ochen, S.; Sserumaga, J.; Alibu, S.; Abalo, G.; et al. Detection of sister-species in invasive populations of the fall armyworm Spodoptera frugiperda (Lepidoptera: Noctuidae) from Uganda. PLoS ONE 2018, 13, e0194571. [CrossRef]

6. Lee, G.; Seo, B.Y.; Lee, J.; Kim, H.; Song, J.H.; Lee, W. First Report of the fall armyworm, Spodoptera frugiperda (Smith, 1797) (Lepidoptera: Noctuidae), a new migratory pest in Korea. Korean J. Appl. Entomol. 2020, 59, 73-78.

7. Uzayisenga, B.; Waweru, B.; Kajuga, J.; Karangwa, P.; Uwumukiza, B.; Edgington, S.; Thompson, E.; Offord, L.; Cafá, G.; Buddie, A. First record of the fall armyworm, Spodoptera frugiperda (J.E. Smith, 1797) (Lepidoptera: Noctuidae), in Rwanda. Afr. Entomol. 2018, 26, 244-246. [CrossRef]

8. Day, R.; Abrahams, P.; Bateman, M.; Beale, T.; Clottey, V.; Cock, M.; Colmenarez, Y.; Corniani, N.; Early, R.; Godwin, J.; et al. Fall armyworm: Impacts and implications for Africa. Outlooks Pest Manag. 2017, 28, 196-201. [CrossRef]

9. Chimweta, M.; Nyakudya, I.W.; Jimu, L.; Mashingaidze, A.B. Fall armyworm [Spodoptera frugiperda (J.E. Smith)] damage in maize: Management options for flood-recession cropping smallholder farmers. Int. J. Pest Manag. 2020, 66, 142-154. [CrossRef]

10. Tambo, J.A.; Day, R.K.; Lamontagne-Godwin, J.; Silvestri, S.; Beseh, P.K.; Oppong-Mensah, B.; Phiri, N.A.; Matimelo, M. Tackling fall armyworm (Spodoptera frugiperda) outbreak in Africa: An analysis of farmers' control actions. Int. J. Pest Manag. 2020, 66, 298-310. [CrossRef]

11. Kumela, T.; Simiyu, J.; Sisay, B.; Likhayo, P.; Mendesil, E.; Gohole, L.; Tefera, T. Farmers' knowledge, perceptions, and management practices of the new invasive pest, fall armyworm (Spodoptera frugiperda) in Ethiopia and Kenya. Int. J. Pest Manag. 2019, 65, 1-9. [CrossRef]

12. Midega, C.A.O.; Pittchar, J.O.; Pickett, J.A.; Hailu, G.W.; Khan, Z.R. A climate-adapted push-pull system effectively controls fall armyworm, Spodoptera frugiperda (J E Smith), in maize in East Africa. Crop Prot. 2018, 105, 10-15. [CrossRef]

13. Johnson, S.J. Migration and the life history strategy of the fall armyworm, Spodoptera frugiperda in the western hemisphere. Int. J. Trop. Insect Sci. 1987, 8, 543-549. [CrossRef]

14. Bateman, M.L.; Day, R.K.; Luke, B.; Edgington, S.; Kuhlmann, U.; Cock, M.J.W. Assessment of potential biopesticide options for managing fall armyworm (Spodoptera frugiperda) in Africa. J. Appl. Entomol. 2018, 142, 805-819. [CrossRef]

15. Yu, S.J. Insecticide resistance in the fall armyworm, Spodoptera frugiperda (J. E. Smith). Pestic. Biochem. Physiol. 1991, 39, 84-91. [CrossRef]

16. Carvalho, R.A.; Omoto, C.; Field, L.M.; Williamson, M.S.; Bass, C. Investigating the molecular mechanisms of organophosphate and pyrethroid resistance in the fall armyworm Spodoptera frugiperda. PLoS ONE 2013, 8. [CrossRef] [PubMed]

17. Gutirrez-Moreno, R.; Mota-Sanchez, D.; Blanco, C.A.; Whalon, M.E.; Terán-Santofimio, H.; Rodriguez-Maciel, J.C.; Difonzo, C. Field-evolved resistance of the fall armyworm (Lepidoptera: Noctuidae) to synthetic insecticides in Puerto Rico and Mexico. J. Econ. Entomol. 2019, 112, 792-802. [CrossRef]

18. Boaventura, D.; Martin, M.; Pozzebon, A.; Mota-Sanchez, D.; Nauen, R. Monitoring of target-site mutations conferring insecticide resistance in Spodoptera frugiperda. Insects 2020, 11, 545. [CrossRef]

19. Guan, F.; Zhang, J.; Shen, H.; Wang, X.; Padovan, A.; Walsh, T.K.; Tay, W.T.; Gordon, K.H.J.; James, W.; Czepak, C.; et al. Whole-genome sequencing to detect mutations associated with resistance to insecticides and Bt proteins in Spodoptera frugiperda. Insect Sci. 2020, 1-12. [CrossRef]

20. Zhang, L.; Liu, B.; Zheng, W.; Liu, C.; Zhang, D.; Zhao, S.; Li, Z.; Xu, P.; Wilson, K.; Withers, A.; et al. Genetic structure and insecticide resistance characteristics of fall armyworm populations invading China. Mol. Ecol. Resour. 2020, 20, 1682-1696. [CrossRef]

21. Hruska, A.J. Fall armyworm (Spodoptera frugiperda) management by smallholders. CAB Rev. Perspect. Agric. Vet. Sci. Nutr. Nat. Resour. 2019, 14, 1-11. [CrossRef]

22. Molina-Ochoa, J.; Lezama-Gutierrez, R.; Gonzalez-Ramirez, M.; Lopez-Edwards, M.; Rodriguez-Vega, M.A.; Arceo-Palacios, F. Pathogens and parasitic nematodes associated with populations of fall armyworm (Lepidoptera: Noctuidae) larvae in Mexico. Fla. Entomol. 2003, 86, 244-253. [CrossRef]

23. Ruiz-Nájera, R.E.; Ruiz-Estudillo, R.A.; Sánchez-Yáñez, J.M.; Molina-Ochoa, J.; Skoda, S.R.; Coutiño-Ruiz, R.; Pinto-Ruiz, R.; Guevara-Hernández, F.; Foster, J.E. Occurrence of entomopathogenic fungi and parasitic nematodes on Spodoptera frugiperda (Lepidoptera: Noctuidae) larvae collected in Central Chiapas, México. Fla. Entomol. 2013, 96, 498-503. [CrossRef]

24. Gardner, W.A.; Fuxa, J.R. Pathogens for the suppression of the fall armyworm. Fla. Entomol. 1980, 63, 439. [CrossRef]

25. Camargo, A.M.; Castañera, P.; Farinós, G.P.; Huang, F. Comparative analysis of the genetic basis of Cry1F resistance in two strains of Spodoptera frugiperda originated from Puerto Rico and Florida. J. Invertebr. Pathol. 2017, 146, 47-52. [CrossRef] 
26. Ashley, T.R. Geographical distribution and parasitization levels for parasitoids of the fall armyworm, Spodoptera frugiperda. Fla. Entomol. 1986, 69, 516-524. [CrossRef]

27. Molina-Ochoa, J.; Hamm, J.J.; Lezama-Gutiérrez, R.; López-Edwards, M.; González-Ramírez, M.; Pescador-Rubio, A. A survey of fall armyworm (Lepidoptera: Noctuidae) parasitoids in the Mexican states of Michoacán, Colima, Jalisco, and Tamaulipas. Fla. Entomol. 2001, 84, 31-36. [CrossRef]

28. Wyckhuys, K.A.G.; O'Neil, R.J. Population dynamics of Spodoptera frugiperda Smith (Lepidoptera: Noctuidae) and associated arthropod natural enemies in Honduran subsistence maize. Crop Prot. 2006, 25, 1180-1190. [CrossRef]

29. Murúa, M.G.; Molina-Ochoa, J.; Fidalgo, P. Natural distribution of parasitoids of larvae of the fall armyworm, Spodoptera frugiperda, in Argentina. J. Insect Sci. 2009, 9, 1-17. [CrossRef]

30. Gutiérrez-Martínez, A.; Tolon-Becerra, A.; Lastra-Bravo, X.B. Biological control of Spodoptera frugiperda eggs using Telenomus remus Nixon in maize-bean-squash polyculture. Am. J. Agric. Biol. Sci. 2012, 7, 285-292. [CrossRef]

31. Hardke, J.T.; Lorenz, G.M.; Leonard, B.R. Fall armyworm (Lepidoptera: Noctuidae) ecology in Southeastern cotton. J. Integr. Pest Manag. 2015, 6. [CrossRef]

32. Hay-Roe, M.M.; Meagher, R.L.; Nagoshi, R.N.; Newman, Y. Distributional patterns of fall armyworm parasitoids in a corn field and a pasture field in Florida. Biol. Control 2016, 96, 48-56. [CrossRef]

33. Meagher, R.L.; Nuessly, G.S.; Nagoshi, R.N.; Hay-Roe, M.M. Parasitoids attacking fall armyworm (Lepidoptera: Noctuidae) in sweet corn habitats. Biol. Control 2016, 95, 66-72. [CrossRef]

34. Liao, Y.L.; Yang, B.; Xu, M.F.; Lin, W.; Wang, D.S.; Chen, K.W.; Chen, H.Y. First report of Telenomus remus parasitizing Spodoptera frugiperda and its field parasitism in southern China. J. Hymenopt. Res. 2019, 93, 95-102. [CrossRef]

35. Firake, D.M.; Behere, G.T. Natural mortality of invasive fall armyworm, Spodoptera frugiperda (J. E. Smith) (Lepidoptera: Noctuidae) in maize agroecosystems of northeast India. Biol. Control 2020, 148, 104303. [CrossRef]

36. Firake, D.M.; Behere, G.T. Bioecological attributes and physiological indices of invasive fall armyworm, Spodoptera frugiperda (J. E. Smith) infesting ginger (Zingiber officinale Roscoe) plants in India. Crop Prot. 2020, 137. [CrossRef]

37. Sisay, B.; Simiyu, J.; Malusi, P.; Likhayo, P.; Mendesil, E.; Elibariki, N.; Wakgari, M.; Ayalew, G.; Tefera, T. First report of the fall armyworm, Spodoptera frugiperda (Lepidoptera: Noctuidae), natural enemies from Africa. J. Appl. Entomol. 2018, 142, 800-804. [CrossRef]

38. Kenis, M.; du Plessis, H.; Van den Berg, J.; Ba, M.N.; Goergen, G.; Kwadjo, K.E.; Baoua, I.; Tefera, T.; Buddie, A.; Cafà, G.; et al. Telenomus remus, a candidate parasitoid for the biological control of Spodoptera frugiperda in Africa, is already present on the continent. Insects 2019, 10, 92. [CrossRef]

39. Agboyi, L.K.; Goergen, G.; Beseh, P.; Mensah, S.A.; Clottey, V.A.; Glikpo, R.; Buddie, A.; Cafà, G.; Offord, L.; Day, R.; et al. Parasitoid complex of fall armyworm, Spodoptera frugiperda, in Ghana and Benin. Insects 2020, 11, 68. [CrossRef]

40. Polaszek, A.; Kimani, S.W. Telenomus species (Hymenopetra: Scelionidae) attacking eggs of pyralid pests (Lepidoptera) in Africa: A review and guide to identification. Bull. Entomol. Res. 1990, 80, 57-71. [CrossRef]

41. Shaw, M.R.; Huddleston, T. Classification and Biology of Braconid Wasps (Hymenoptera: Braconidae); Dolling, W.R., Askew, R., Eds.; The British Museum (Natural History): London, UK, 1991; Volume 7.

42. Fiaboe, K.K.M.; Fernández-Triana, J.; Nyamu, F.W.; Agbodzavu, K.M. Cotesia icipe Sp. N., a new Microgastrinae wasp (Hymenoptera: Braconidae) of importance in the biological control of Lepidopteran pests in Africa. J. Hymenopt. Res. 2017, 61, 49-64. [CrossRef]

43. Aguirre, H.; de Almeida, L.F.; Shaw, S.R.; Sarmiento, C.E. An illustrated key to Neotropical species of the genus Meteorus Haliday (Hymenoptera, Braconidae, Euphorinae). Zookeys 2015, 489, 33-94. [CrossRef] [PubMed]

44. Gauld, I.D. An Introduction to the Ichneumonidae of Australia; British Museum (Natural History): London, UK, 1984; 413p, ISBN 0565008951.

45. O'Hara, J.E.; Shima, H.; Zhang, C. Annotated catalogue of the Tachinidae (Insecta: Diptera) of China. Zootaxa 2009, 2190, 1-236. [CrossRef]

46. O'Hara, J.E.; Cerretti, P. Annotated catalogue of the Tachinidae (Insecta, Diptera) of the Afrotropical Region, with the description of seven new genera. Zookeys 2016, 2016, 1-344. [CrossRef] [PubMed]

47. Yao, H.; Song, J.; Liu, C.; Luo, K.; Han, J.; Li, Y.; Pang, X.; Xu, H.; Zhu, Y.; Xiao, P.; et al. Use of ITS2 region as the universal DNA barcode for plants and animals. PLoS ONE 2010, 5, e13102. [CrossRef]

48. Staden, R.; Beal, K.F.; Bonfield, J.K. The Staden package, 1998. Methods Mol. Biol. 2000, 132, 115-130. [CrossRef]

49. Kearse, M.; Moir, R.; Wilson, A.; Stones-Havas, S.; Cheung, M.; Sturrock, S.; Buxton, S.; Cooper, A.; Markowitz, S.; Duran, C.; et al. Geneious Basic: An integrated and extendable desktop software platform for the organization and analysis of sequence data. Bioinformatics 2012, 28, 1647-1649. [CrossRef]

50. Sayers, E.W.; Beck, J.; Brister, J.R.; Bolton, E.E.; Canese, K.; Comeau, D.C.; Funk, K.; Ketter, A.; Kim, S.; Kimchi, A.; et al. Database resources of the National Center for Biotechnology Information. Nucleic Acids Res. 2020, 48, D9-D16. [CrossRef]

51. Ratnasingham, S.; Hebert, P.D.N. BOLD: The Barcode of Life Data System: Barcoding. Mol. Ecol. Notes 2007, 7, 355-364. [CrossRef]

52. Katoh, K.; Misawa, K.; Kuma, K.I.; Miyata, T. MAFFT: A novel method for rapid multiple sequence alignment based on fast Fourier transform. Nucleic Acids Res. 2002, 30, 3059-3066. [CrossRef]

53. Katoh, K.; Standley, D.M. MAFFT multiple sequence alignment software version 7: Improvements in performance and usability. Mol. Biol. Evol. 2013, 30, 772-780. [CrossRef] 
54. Trifinopoulos, J.; Nguyen, L.T.; von Haeseler, A.; Minh, B.Q. W-IQ-TREE: A fast online phylogenetic tool for maximum likelihood analysis. Nucleic Acids Res. 2016, 44, W232-W235. [CrossRef] [PubMed]

55. Huson, D.H.; Scornavacca, C. Dendroscope 3: An interactive tool for rooted phylogenetic trees and networks. Syst. Biol. 2012, 61, 1061-1067. [CrossRef] [PubMed]

56. Ramage, T.; Martins-Simoes, P.; Mialdea, G.; Allemand, R.; Duplouy, A.; Rousse, P.; Davies, N.; Roderick, G.K.; Charlat, S. A DNA barcode-based survey of terrestrial arthropods in the Society Islands of French Polynesia: Host diversity within the SymbioCode project. Eur. J. Taxon. 2017, 2017, 1-13. [CrossRef]

57. Sow, A.; Brévault, T.; Delvare, G.; Haran, J.; Benoit, L.; d'Acier, A.C.; Galan, M.; Thiaw, C.; Soti, V.; Sembène, M. DNA sequencing to help identify crop pests and their natural enemies in agro-ecosystems: The case of the millet head miner Heliocheilus albipunctella (Lepidoptera: Noctuidae) in sub-Saharan Africa. Biol. Control 2018, 121, 199-207. [CrossRef]

58. Sharkey, M.J.; Chapman, E.G. Phylogeny of the Agathidinae (Hymenoptera: Braconidae) with a revised tribal classification and the description of a new genus. In Proceedings of the Entomological Society of Washington, Washington, DC, USA, 1 December 2017; Volume 119, pp. 823-842.

59. Sharkey, M.J.; Chapman, E.G. The Nearctic genera of Agathidinae (Hymenoptera: Braconidae) with a phylogenetic analysis, illustrated generic key, and the description of three new genera. Zootaxa 2015, 4000, 49-72. [CrossRef]

60. Koffi, D.; Kyerematen, R.; Eziah, V.Y.; Agboka, K.; Adom, M.; Goergen, G.; Meagher, R.L. Natural enemies of the fall armyworm, Spodoptera frugiperda (J.E. Smith) (Lepidoptera: Noctuidae) in Ghana. Fla. Entomol. 2020, 103, 85. [CrossRef]

61. Van Noort, S. WaspWeb: Hymenoptera of the Afrotropical Region. Iziko Museums of South Africa. Available online: www.waspweb. org (accessed on 23 July 2020).

62. Agboyi, L.K.; Mensah, S.A.; Clottey, V.A.; Beseh, P.; Glikpo, R.; Rwomushana, I.; Day, R.; Kenis, M. Evidence of leaf consumption rate decrease in fall armyworm, Spodoptera frugiperda, larvae parasitized by Coccygidium luteum. Insects 2019, 10, 410. [CrossRef]

63. Gupta, A.; Soujanya, P.L.; van Achterberg, C.; Sekhar, J.C. Coccygidium transcaspicum (Kokujev) (Hymenoptera: Braconidae) parasitizing larvae of invasive pest Spodoptera frugiperda (J. E. Smith) (Lepidoptera: Noctuidae) in India. Zootaxa 2020, 4750, 293-297. [CrossRef]

64. Sharanabasappa, D.; Kalleshwaraswamy, C.M.; Poorani, J.; Maruthi, M.S.; Pavithra, H.B.; Diraviam, J. Natural enemies of Spodoptera frugiperda (J. E. Smith) (Lepidoptera: Noctuidae), a recent invasive pest on maize in South India. Fla. Entomol. 2019, 102, 619-623. [CrossRef]

65. Rao, G.V.R.; Wightman, J.A.; Rao, D.V.R. World review of the natural enemies and diseases of Spodoptera litura (F.) (Lepidoptera: Noctuidae). Int. J. Trop. Insect Sci. 1993, 14, 273-284. [CrossRef]

66. Stevens, N.B.; Austin, A.D.; Jennings, J.T. Synopsis of Australian Agathidine wasps (Hymenoptera: Braconidae: Agathidinae). Zootaxa 2010, 2480, 1-26. [CrossRef]

67. Ngangambe, M.H.; Mwatawala, M.W. Effects of entomopathogenic fungi (EPFs) and cropping systems on parasitoids of fall armyworm (Spodoptera frugiperda) on maize in eastern central, Tanzania. Biocontrol Sci. Technol. 2020, 30, 418-430. [CrossRef]

68. Zenner, I.; Álvarez, A.; Barreto, S. Influence of parasitism by Chelonus insularis Cresson (Hymenoptera: Braconidae) on the susceptibility of Spodoptera frugiperda (J.E. Smith) (Lepidoptera: Noctuidae) to insecticides. Neotrop. Entomol. 2006, 35, 818-822. [CrossRef] [PubMed]

69. Kittel, R.N.; Austin, A.D.; Klopfstein, S. Molecular and morphological phylogenetics of Chelonine parasitoid wasps (Hymenoptera: Braconidae), with a critical assessment of divergence time estimations. Mol. Phylogenet. Evol. 2016, 101, 224-241. [CrossRef] [PubMed]

70. Zhang, Z.; Schwartz, S.; Wagner, L.; Miller, W. A greedy algorithm for aligning DNA sequences. J. Comput. Biol. 2000, 7, 203-214. [CrossRef] [PubMed]

71. Laminou, S.A.; Ba, M.N.; Karimoune, L.; Doumma, A.; Muniappan, R. Parasitism of locally recruited egg parasitoids of the fall armyworm in Africa. Insects 2020, 11, 430. [CrossRef] [PubMed]

72. Kankonda, O.M.; Akaibe, B.D.; Sylvain, N.M.; Le Ru, B.P. Response of maize stemborers and associated parasitoids to the spread of grasses in the rainforest zone of Kisangani, DR Congo: Effect on stemborers biological control. Agric. Entomol. 2018, 20, 150-161. [CrossRef]

73. Hordzi, W.H.K. Lepidopterous stem borers of maize (Zea mays): Agro-ecological and regional composition and distribution of their parasitoids in Southern Ghana. J. Biosci. Biotechnol. Discov. 2018, 3, 46-58. [CrossRef]

74. Smith, M.A.; Fernández-Triana, J.L.; Eveleigh, E.; Gómez, J.; Guclu, C.; Hallwachs, W.; Hebert, P.D.N.; Hrcek, J.; Huber, J.T.; Janzen, D.; et al. DNA barcoding and the taxonomy of Microgastrinae wasps (Hymenoptera, Braconidae): Impacts after 8 years and nearly 20000 sequences. Mol. Ecol. Resour. 2013, 13, 168-176. [CrossRef]

75. Muirhead, K.A.; Murphy, N.P.; Sallam, N.; Donnellan, S.C.; Austin, A.D. Phylogenetics and genetic diversity of the Cotesia flavipes complex of parasitoid wasps (Hymenoptera: Braconidae), biological control agents of Lepidopteran stemborers. Mol. Phylogenet. Evol. 2012, 63, 904-914. [CrossRef]

76. Jourdie, V.; Alvarez, N.; Turlings, T.C.J. Identification of seven species of Hymenopteran parasitoids of Spodoptera frugiperda, using polymerase chain reaction amplification and restriction enzyme digestion. Agric. Entomol. 2008, 10, 129-136. [CrossRef]

77. De Freitas, J.G.; Takahashi, T.A.; Figueiredo, L.L.; Fernandes, P.M.; Camargo, L.F.; Watanabe, I.M.; Foerster, L.A.; Fernandez-Triana, J.; Shimbori, E.M. First record of Cotesia scotti (Valerio and Whitfield, 2009) (Hymenoptera: Braconidae: Microgastrinae) comb. nov. parasitising Spodoptera cosmioides (Walk, 1858) and Spodoptera eridania (Stoll, 1782) (Lepidoptera: Noctuidae) in Brazil. Rev. Bras. Entomol. 2019, 63, 238-244. [CrossRef] 
78. Desneux, N.; Ramírez-Romero, R.; Bokonon-Ganta, A.H.; Bernal, J.S. Attraction of the parasitoid Cotesia marginiventris to host (Spodoptera frugiperda) frass is affected by transgenic maize. Ecotoxicology 2010, 19, 1183-1192. [CrossRef] [PubMed]

79. Van Nouhuys, S.; Tay, W.T. Causes and consequences of small population size for a specialist parasitoid wasp. Oecologia 2001, 128, 126-133. [CrossRef] [PubMed]

80. López, M.A.; Martínez-Castillo, A.M.; García-Gutiérrez, C.; Cortez-Mondaca, E.; Escobedo-Bonilla, C.M. Parasitoids and entomopathogens associated with fall armyworm, Spodoptera frugiperda, in Northern Sinaloa. Southwest. Entomol. 2018, 43, 867-881. [CrossRef]

81. Yu, D.S.K.; van Achterberg, C.; Horstmann, K. Taxapad 2016, Ichneumonoidea 2015; Database on Flash-Drive: Nepean, ON, Canada, 2016; Available online: http:/ / www.taxapad.com (accessed on 4 September 2020).

82. Fernandez-Triana, J. Ten unique and charismatic new species of microgastrinae wasps (Hymenoptera: Braconidae) from North America. Zookeys 2018, 2018, 123-150. [CrossRef]

83. Caniço, A.; Mexia, A.; Santos, L. First report of native parasitoids of fall armyworm Spodoptera frugiperda smith (Lepidoptera: Noctuidae) in Mozambique. Insects 2020, 11, 615. [CrossRef]

84. Tendeng, E.; Labou, B.; Diatte, M.; Djiba, S.; Diarra, K. The fall armyworm Spodoptera frugiperda (J.E. Smith), a new pest of maize in Africa: Biology and first native natural enemies detected. Int. J. Biol. Chem. Sci. 2019, 13, 1011. [CrossRef] 